\title{
Contamination and Pollution of Ground Water in Pakur District of Jharkhand
}

\author{
Dumraj Saha \\ Assistant Teacher, +2 National High School, Dumka
}

\begin{abstract}
The chemical pollution of water causes changes in acidity, alkalinity or pH and dissolved oxygen. It may be caused either by organic pollutants or inorganic pollutants or by both. The organic pollutants can be biodegradable or non-biodegradable. Biodegradable organic pollutants include proteins from domestic sewage. Non-biodegradable organic pollutants are those which persist in the aquatic system for a long time. Bacterial pollution in water is caused by the excretory products of man, animals and birds. The main pollutants belong to coliform group and certain subgroups, facial streptococci and miscellaneous organisms. Biological pollution is also brought about by bacteria, viruses, algae, diatoms like protozoa, rotifers, crustaceans and plants toxins. Physiological pollution of water is caused by several chemical agents such as chlorine, sulphur dioxide, hydrogen sulphide, ketones, phenols, amines, mercaptans and hydroxy benzene.
\end{abstract}

Keywords: Chemical pollution, Jharkhand, Pakur District, Ground Water, Toxins

\section{Introduction}

Groundwater crisis is not the result of natural factors; it has been caused by human actions. During the past two decades, the water level in several parts of the country has been falling rapidly due to an increase in extraction. The number of wells drilled for irrigation of both food and cash crops has rapidly and indiscriminately increased. India's rapidly rising population and changing lifestyles have also increased the domestic need for water. The water requirement for the industry also shows an overall increase.

Intense competition for groundwater among usersagriculture, Industry and domestic sectors is driving the groundwater table lower. The quality of groundwater is getting severely affected because of the widespread pollution of surface water. Besides, discharge of untreated waste water through bores and leachate from unscientific disposal of solid wastes also contaminates groundwater, thereby reducing the quality of fresh water resources.

\section{Sources of Ground Water Contamination}

Pollution of groundwater resources has become a major problem today. The pollution of air, water and land has an affect on the pollution and contamination of groundwater. The solid, liquid and the gaseous waste that is generated, if not treated properly, results in pollution of the environment; this affects groundwater too due to the hydraulic connectivity in the hydrological cycle. For example, when the air is polluted, rainfall will settle many pollutants on the ground, which can then percolates and contaminate the groundwater resources. Water extraction without proper recharge and leaching of addition, leachates from agriculture, industrial waste and the municipal solid waste have also polluted surface and groundwater. Some 45 million people the world over the affected by water pollution marked by excess fluoride, arsenic, iron or the ingress of salt water.

\section{Ground Water Pollution}

Untreated underground water is often much purer and cleaner than any surface water. However, even underground water are now threatened with pollution from seepage, pits, refuge dumps, septic tanks, barnyard manures, transport accidents etc. and with diverse agricultural, chemical or biological pollutants. Other important sources of pollution of ground waters include sewage and soluble salts coming with seepage and water as soluble constituents also present in the soil.

\section{Conclusion}

The main objective of the present study is the resource assessment potential of ground water with special reference to the environmental affects as well as its quality an quantity. Field studies made by the present author aim at deciphering the nature and extent of ground water resources, the quality of ground water available and the nature and extent of the possible aquifer formations. The studies include preparation of maps of groundwater table and its seasonal variation, systematic collection of water samples from different dug wells, hand pumps and tube wells and their subsequent chemical analyses finding out the degree of ground water mineralisation and resources evaluation of groundwater from the available data. It is also envisaged to study the agrochemical characteristic of ground water occurring in different parts of the region in order to assess the pollution of ground water if any.

\section{References}

[1] West, Larry: "World Water Day; A Billion People Worldwide Lack Safe Drinking Water", (2006).

[2] United States Geological Survey (USGS), Denver, CO: "Ground Water and Surface Water: (1998).

[3] Pink, Daniel H. : "Investing in Tomorrow's Liquid Gold" (2006). 
[4] C. Michael Hogan : "Water pollution." Encyclopedia of Earth. Topic ed. Mard McGinley;ed. in chief $\mathrm{C}$. Cleveland. National Council on Science and the Environment, Washington, DC, (2010).

[5] S. Binu Kumari, K. Vijayakumar, M. Manimegalal and D.Yasotha : Asian Journal of chemical and Environmental Research ; vol. 4(1), 5-8, January (2011). 